\title{
Apparent selective elemental disequilibrium between melt and mineral phases of the Haramul Mic lava dome
}

\author{
EMESE PÁNCZÉL ${ }^{1}$, MAURIZIO PETRELLI ${ }^{2}$, RÉKA \\ LUKÁCS $^{3}$, OLIVIER BACHMANN ${ }^{4}$ AND SZABOLCS \\ HARANGI ${ }^{1,3}$ \\ ${ }^{1}$ Institute of Geography and Earth Sciences, Eötvös Loránd \\ University \\ ${ }^{2}$ University of Perugia \\ ${ }^{3}$ MTA-ELTE Volcanology Research Group \\ ${ }^{4}$ ETH Zürich \\ Presenting Author: emipanczel7@gmail.com
}

Haramul Mic is a $\sim 0.15 \mathrm{~km}^{3}$ volume, crystal-rich, homogeneous, high-K dacite lava dome, which erupted in the Ciomadul Volcanic Complex (Romania, eastern-central Europe) $\sim 160$ kyrs ago after $\sim 200$ kyrs of quiescence. The lava dome rock has average crystal content of $35-40 \%$, and the mineral assemblage consists of plagioclase, amphibole, biotite and accessory zircon, apatite, titanite and Fe-Ti oxides. The groundmass is mainly formed by perlitic glass with some microlites and sheared vesicles. Felsic crystal clots are common which comprise plagioclase, amphibole, biotite and interstitial vesicular glass $(<10 \%)$. The dacite contains sparse enclaves with K-rich bulk composition, mainly composed of plagioclase and biotite, less amount of amphibole and interstitial glass $(<10 \%)$.

Trace element content of glass and mineral phases was determined by LA-ICP-MS. The studied phases are slightly zoned but the last crystallization zones show mostly homogeneous compositions suggesting general equilibrium state in the magma storage system at $700-800{ }^{\circ} \mathrm{C}$ and $200-300 \mathrm{MPa}$ before eruption. Exceptions are $\mathrm{Li}, \mathrm{Sc}$ and $\mathrm{Cr}$ which have different concentrations in the host rock and the enclaves. The calculated mineral-melt trace element partition coefficients show similarities with those proposed for the Fish Canyon Tuff dacite (Bachmann et al., 2005) except for Li, Sc and Cr.

Glass in the enclave is enriched in $\mathrm{Sc}$ and $\mathrm{Li}$ compared to the groundmass glass of the host dacite. On the other hand, biotite in the enclave is enriched in $\mathrm{Li}$ and depleted in Sc compared to the biotite of the host rock. Li decreases rimward along plagioclase profiles in the dacite. The Li concentration differences may be interpreted as the result of degassing / diffusion during magma ascent and cooling. However, this is not observed in the enclave and the felsic clot implying retention of $\mathrm{Li}$ in the intercrystalline melt. Differences in $\mathrm{Sc}$ and $\mathrm{Cr}$ concentrations could be due to microlite content of the groundmass glass or suggest distinct magma batches within the magma reservoir.

This research belongs to the NKFIH-K135179 project.

Bachmann et al., 2005: CMP, 149(3), 338-349. 